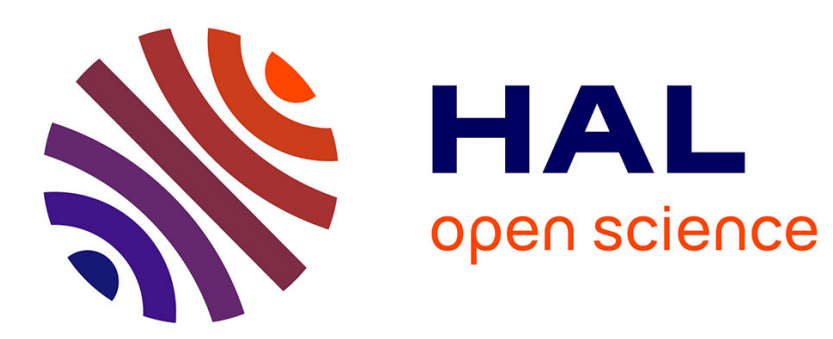

\title{
Antibiosis of forage soybean as an ecological alternative for the control of corn earworm
}

\author{
Iqbal Javaid, Robert B. Dadson, Fawzy M. Hashem, Jagmohan Joshi
}

\section{To cite this version:}

Iqbal Javaid, Robert B. Dadson, Fawzy M. Hashem, Jagmohan Joshi. Antibiosis of forage soybean as an ecological alternative for the control of corn earworm. Agronomy for Sustainable Development, 2006, 26 (1), pp.55-59. hal-00886322

\section{HAL Id: hal-00886322 \\ https://hal.science/hal-00886322}

Submitted on 1 Jan 2006

HAL is a multi-disciplinary open access archive for the deposit and dissemination of scientific research documents, whether they are published or not. The documents may come from teaching and research institutions in France or abroad, or from public or private research centers.
L'archive ouverte pluridisciplinaire HAL, est destinée au dépôt et à la diffusion de documents scientifiques de niveau recherche, publiés ou non, émanant des établissements d'enseignement et de recherche français ou étrangers, des laboratoires publics ou privés. 


\title{
Antibiosis of forage soybean as an ecological alternative for the control of corn earworm
}

\author{
Iqbal JAVAID*, Robert B. DADSON, Fawzy M. HASHEM, Jagmohan JOSHI \\ Department of Agriculture, University of Maryland Eastern Shore, Crop Research and Aquaculture Building, \\ 30921 Martin Court, Princess Anne, MD 21853-1299, USA
}

(Accepted 25 October 2005)

\begin{abstract}
The present study is the first to document some antibiosis type of resistance in forage soybeans. The production of forage soybean is increasing in the United States where about 500000 acres are now grown annually in various soybean growing areas. However, production is limited by the corn earworm Helicoverpa zea Boddie, which is a major insect pest of soybean. An in vitro study of field grown soybean leaves was conducted to select forage soybean genotypes for antibiosis type resistance to corn earworm. The feeding tests were conducted on excised leaf material from a randomized complete block design. The results showed significant differences in the weight of corn earworm larvae, which were allowed to feed on different genotypes of fodder soybean. The mean larval weights on genotypes Tara, 7P116 and 8 GH 85-2 were 245.8, 242.1 , and $169.3 \mathrm{mg}$, respectively. These genotypes were found to be most susceptible to corn earworm while the tall growing vegetable cultivar Moon Cake with the mean larval weight of 94.8 showed some antibiosis types of resistance.
\end{abstract}

antibiosis / corn earworm / forage soybean / host plant resistance

\section{INTRODUCTION}

Livestock producers have shown renewed interest in growing and ensiling forage soybean as an alternative or supplemental source of legume protein. Although soybean was initially used as forage when introduced to the United States in the late 1800s (Seiter et al., 2004) soybean is currently grown mainly as a grain crop. A smaller acreage is used for forage and hay production. In the Northern United States, soybean use for forage is often practiced when crop damage limits grain harvest (Sheaffer et al., 2001). In the Southeastern US, disease problems limit the use of perennial forage legumes, and soybeans are sometimes planted with the intended use as forage. Approximately 500000 acres of fodder soybean are grown annually in the USA. The recent increase in interest in growing soybean as a forage crop has been partly due to the availability of soybean cultivars that were bred for use as forage (Devine and Hatley, 1998; Devine et al., 1998a, b; Nayighugu, 2002; Seiter et al., 2004). Forage soybean can be a viable alternative source of legume protein and also a beneficial crop when grown in rotation with corn (Hintz et al., 1992). Also, in Europe there has been a surge of interest in the production of various protein crops due to the banning of the use of most animal proteins in ruminant diets in the EU (Koivisto et al., 2003).

Soybean is susceptible to various insect pests. Of these, corn earworm (Helicoverpa zea) larvae can cause extensive damage to newly formed pods of soybean. Corn earworm has been reported as the most serious insect pest of soybean in the MidAtlantic States and Southern Coastal Plain (Stinner et al., 1980). The eggs are laid on the newly formed leaves and larvae feed upon the young foliage (Fig. 1A). Late migration of older larvae to the developing pods and pod feeding (Fig. 1B) may cause severe economic losses. The adult moth (Fig. 1C) is attracted to soybean at the time of flowering (Johnson et al., 1975) and each larva is capable of damaging 6 to 8 pods of soybean per plant (Eckel et al., 1992; Smith and Bass, 1972; Mebrahtu et al., 2002). In Virginia, corn earworm has been reported to cause losses, including treatment costs, of more than $\$ 2.5$ million in certain years. Losses in excess of \$4.4 million have been reported in Georgia (Douce and Suber, 1986). Millions of dollars are spent annually on insecticides for the control of corn earworm and other insect pests of soybean (Paschal and Rogers, 1980). However, there is very little information on the losses caused by corn earworm in fodder soybean.

The application of insecticide increases the cost of grain and fodder soybean production and has other well-known side effects such as the pollution of soil, streams and lakes (Pedigo, 1989; Javaid and Joshi, 1995). The threshold levels for the application of insecticides for the control of key insect pests, such as corn earworm in fodder soybean, are not available. Little is known about residue limits for feeding forage to animals. The use of insecticides for the management of insect pests of fodder soybean seems undesirable economically and ecologically. Host plant resistance integrated with other

\footnotetext{
*Corresponding author: ijavaid@umes.edu; iqbal_javaid3@hotmail.com
} 

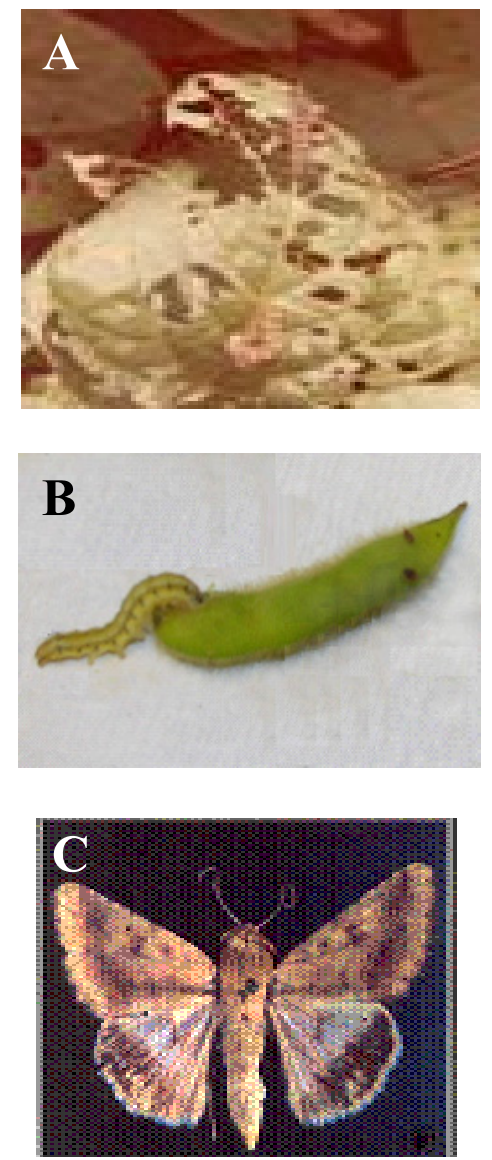

Figure 1. Corn earworm larvae feeding on soybean leaves (A), feeding on a soybean pod (B) and corn earworm adult (C).

non-chemical methods of pest control deserves more attention. Development of forage soybean varieties resistant to corn earworm is highly desirable economically and ecologically. Selection of insect resistance in soybean has also been suggested as an important component of several breeding programs in the United States (Hatchett et al., 1979; Gary et al., 1985).

In previous studies, antibiosis type of resistance to corn earworm feeding (Painter, 1991) was reported in various soybean breeding lines (Beland and Hatchet, 1976; Hatchett et al., 1976; Joshi, 1981; Mebrahtu et al., 2002; Javaid et al., 1991). Antibiosis to corn earworm has also been reported in vegetable soybean (Kraemer et al., 1997; Joshi et al., 1992) and in tofu soybean (Kraemer, 2001). There is, however, no information available on the antibiosis type of resistance to corn earworm in forage soybean. Therefore, this study was conducted to evaluate breeding lines of forage soybean for antibiosis to corn earworm.

\section{MATERIALS AND METHODS}

Eleven forage, one grain and one vegetable soybean genotypes were included in the present study. The selection of these lines was based upon promising agronomic results in the Del- marva region of the US. Soybeans were planted in the field in a randomized complete block design with four replications. The details of breeding lines included in the study are given in Table I. The breeding lines were planted on June 10, 2004 at the Agricultural Research Station, Department of Agriculture, University of Maryland Eastern Shore, Princess Anne, Maryland. There were four rows in each plot and each row was $5 \mathrm{~m}$ long with $0.75 \mathrm{~m}$ spacing between rows and $5 \mathrm{~cm}$ between plants. No insecticides were applied during the growing season. The plots and replications were separated by a spacing of $2 \mathrm{~m}$. The physical and chemical analyses of the soils were conducted at the Soil Testing Laboratory of the University of Maryland College Park, Maryland. The soil texture of the experimental site was silt loam. Physical analyses of the soil were $64 \%$ sand, $22 \%$ silt, $14 \%$ clay, and with CEC 4.59 . The chemical analyses results of the soils were: $\mathrm{Mg}: 89 \mathrm{~kg} \mathrm{ha}^{-1}, \mathrm{P}: 172 \mathrm{~kg} \mathrm{ha}^{-1}, \mathrm{~K}$ : $91 \mathrm{~kg} \mathrm{ha}^{-1}$, Ca: $41 \mathrm{~kg} \mathrm{ha}^{-1}$, OM: $2.3 \%, \mathrm{NO}_{3}-\mathrm{N}: 6.60 \mathrm{~kg} \mathrm{ha}^{-1}$, and $\mathrm{pH}: 6.1$.

The first bioassay test was started as soon as the breeding lines had started flowering and was followed by the second bioassay ten days later. The newly formed trifoliolates were excised with a pair of sterile scissors from each replication of each breeding line. The leaves were placed in plastic bags and after labeling were transported to the laboratory in a cooler to avoid wilting. Each trifoliolate was cut into three leaflets and each leaflet was placed in a sterile petri dish, which had a moist filter paper at the bottom. Petri dish bioassays can be useful tools to evaluate antibiosis-type of resistance to defoliating insects especially corn earworm (Kraemer et al., 1997). During the bioassay studies, the tables, scissors and brushes were disinfected with a solution of Clorox to avoid pathogenic infections to corn earworm larvae. Two bioassays were conducted at room temperature using ten petri dishes per replication. The data were analyzed using SAS package (SAS Inst., 1996) as a randomized complete block design and significant means were separated by Duncan's Multiple Range Tests (Duncan, 1955; Steel and Torrie, 1980). The results of combined analysis are shown in Figure 2.

Corn earworm eggs were obtained from the Southern Insect Management Unit, USDA, Agricultural Research Service Stoneville, Mississippi. Three neonatal larvae were placed in leaflets in each petri dish. The weight of newly hatched larvae was not recorded. Most of the larvae hatched on the same day. The filter papers at the bottom of each petri dish were kept moist by adding $1 \mathrm{~mL}$ of distilled sterile water at an interval of every other day. The foliage and filter papers were replaced at an interval of two days. After three days, we reduced the number of larvae in each petri dish to one. The larvae which looked the largest were kept for further rearing. At day 10, the weights of larvae were recorded.

\section{RESULTS AND DISCUSSION}

There were significant differences in the weights of corn earworms that were reared on various genotypes of forage soybean in both bioassays (Tab. II). Results showed variation in the susceptibility of forage soybean breeding lines to corn earworm. The breeding lines on which the corn earworm larvae had the lowest larval weights (Fig. 2) such as Moon Cake, Hutcheson, 
Table I. Pedigree, maturity group, pubescence color, dormancy and usage type of soybean lines.

\begin{tabular}{|c|c|c|c|c|c|}
\hline Breeding Lines & Pedigree & Maturity group & Pubescence color & Determinacy & Usage type \\
\hline Tara & OR5-12-IT × OR13-11-4-3-2-1 & $\mathrm{V}$ & $\mathrm{T}$ & I & Forage \\
\hline $8 \mathrm{GH} 85-2$ & Prolina $\times($ PA20-1-1 $\times$ Spray $)$ & VI & $\mathrm{T}$ & I & Forage \\
\hline 7 P116 & PA7-1-1 × Spry 20 & VI & $\mathrm{T}$ & I & Forage \\
\hline 8GH61-1-1 G & Hutcheson $\times($ OR5-12-2 $\times$ Emerald $)$ & VIII & G & I & Forage \\
\hline F5, 95-1 & $($ PA5-1-1 $\times$ Verde $) \times($ PA15-1-1 $\times$ Spray $)$ & VII & G & I & Forage \\
\hline Tyrone & PA4-11g $\times$ Ripley & VII & G & I & Forage \\
\hline F5, 97-1 & $($ PA5-1-1 × Verde $) \times$ C PA15-1-1 × Spry $)$ & $\mathrm{V}$ & $\mathrm{T}$ & I & Forage \\
\hline XB-32 & OR5-12-2 × Spry & VI & $\mathrm{T}$ & $\mathrm{D}$ & Grain/Forage \\
\hline SG 13\#53 & Hutcheson $\times$ OR13-11-4-3-2-1 & VI & $\mathrm{T}$ & I & Forage \\
\hline Donegal & PA 4-11b $\times$ Burlison & $\mathrm{V}$ & $\mathrm{T}$ & I & Forage \\
\hline 97 VA 5 & OR5-12-IT × OR 13-11-4-3-2-1 & VI & $\mathrm{T}$ & I & Forage \\
\hline Hutcheson & V68-1034 × Essex & $\mathrm{V}$ & G & $\mathrm{D}$ & Grain \\
\hline Moon Cake & OR5-12-1T $\times$ Disoy & $\mathrm{V}$ & $\mathrm{G}$ & I & Vegetable \\
\hline
\end{tabular}

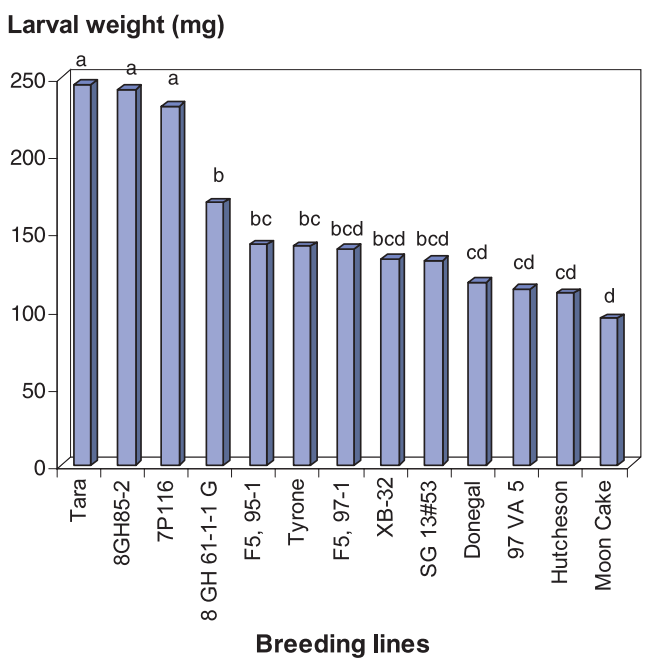

Figure 2. Mean weight of corn earworm larvae on forage soybean breeding lines. Bars with the same letters are not significantly different according to Duncan's multiple range tests.

95 VA 5 and Donegal were regarded as having some antibiosis resistance (Painter, 1991) against corn earworm, whereas the breeding lines such as Tara, 8GH 86-2 and 7P 116 on which the corn earworm larvae had the highest weights were regarded as susceptible. In addition to the identification of resistant genotypes, the identification of susceptible varieties is important to avoid excessive reliance on pesticides (Kraemer, 2001). The mean larval weights ranged from $99 \mathrm{mg}$ to $228 \mathrm{mg}$ in bioassay 1, and 90 to 263 in bioassay 2. With few exceptions, the results were generally similar in both tests. Indeed, the resistance to corn earworm in some crops influences early development rates much more than ultimate rates (Gary et al., 1985). Also, Beach and Todd (1988) indicated that 5 to 8 days of development are accurate and time efficient measurements of various lepidopterous insect pests. The antibiosis (Painter,
1991) tests were able to separate the susceptibility of fodder soybean genotypes to corn earworm. The petri dish bioassay measures antibiosis-type resistance and is generally considered as good indicator of resistance in the field. It can be a useful tool to evaluate antibiosis-type resistance to defoliating insects, especially when corn earworm infestations cannot be assured in the field. Also, Petri dish bioassays have shown to correlate well with field observations (Kraemer, 2001).

The results suggest that sufficient genetic variation exists among forage soybean breeding lines to make further improvement in pest resistance in fodder soybean breeding. The resistance based on antibiosis is more reliable because non preference may vary with the type of alternative plant hosts in the area (Mebrahtu et al., 2002). Host plant resistance in fodder

Table II. Larval weights (mg) of corn earworm fed on 13 forage soybean lines grown in the Delmarva region of United States. Moon Cake provided some antibiosis (lowest mean weight of larvae) and Tara was susceptible (maximum mean weight of larvae).

\begin{tabular}{lcc}
\hline Soybean Breeding Lines & Bioassay 1 & Bioassay 2 \\
\hline Tara & $228.4^{\mathrm{a}}$ & $263.2^{\mathrm{a}}$ \\
$8 \mathrm{GH} 85-2$ & $220.6^{\mathrm{ab}}$ & $263.5^{\mathrm{a}}$ \\
7P116 & $213.2^{\mathrm{ab}}$ & $249.2^{\mathrm{a}}$ \\
8 GH 61-1-1 G & $160.4^{\mathrm{cd}}$ & $178.1^{\mathrm{b}}$ \\
F5, 95-1 & $130.0^{\mathrm{cde}}$ & $154.6^{\mathrm{b}}$ \\
Tyrone & $128.6^{\mathrm{de}}$ & $153.5^{\mathrm{b}}$ \\
F5, 97-1 & $140.4^{\mathrm{cde}}$ & $138.9^{\mathrm{bcd}}$ \\
XB-32 & $123.6^{\mathrm{de}}$ & $141.9^{\mathrm{bcd}}$ \\
SG 13\#53 & $134.0^{\mathrm{cde}}$ & $130.0^{\mathrm{bcd}}$ \\
Donegal & $121.5^{\mathrm{de}}$ & $114.3^{\mathrm{bcd}}$ \\
97 VA 5 & $106.6^{\mathrm{e}}$ & $120.7^{\mathrm{bcd}}$ \\
Hutcheson & $139.6^{\mathrm{cde}}$ & $82.4^{\mathrm{d}}$ \\
Moon Cake & $99.3^{\mathrm{e}}$ & $90.3^{\mathrm{cd}}$ \\
\hline
\end{tabular}

Means followed by the same letter in a column are not significantly different according to Duncan's multiple range tests. 
soybean should deserve more attention in the breeding and improvement programs in the United States and other parts of the world to sustain the cropping systems. The partial or intermediate antibiosis type of resistance which was observed in some genotypes of fodder soybean could play an important role in reducing the use of insecticides resulting in reduced risk to the environment (Javaid et al., 1991). The evaluation of insect pest resistance in soybean has been emphasized because it reduces dependence on pesticides, lower production costs, and improves the seed quality. The development of insect resistance in fodder soybean deserve more attention in different parts of the world. It might not involve additional costs or inputs to the farmers (Singh, 1987). It will reduce the use of insecticides and will also increase grower's profitability (Wiseman, 1985). The recent interest in the production of forage soybean in various parts of the USA and the availability of forage soybean varieties (Devine, 1998; Nayighugu, 2002) call for more studies on the evaluation of non-chemical and economical methods such as host plant resistance for the management of various key insect pests. Some of the high yielding and tall fodder soybean breeding lines might be more attractive for insect pests compared with the grain soybean. The main benefits of host plant resistance in fodder soybean could be its compatibility with other strategies such as cultural and biological control practices.

\section{CONCLUSION}

The tall growing vegetable cultivar Moon Cake which had the minimum larval weight (94.8 $\mathrm{mg}$ ) was found to possess the most antibiosis type of resistance to corn earworm. Some of the other breeding lines were also not significantly different from the level of resistance shown by Moon Cake. The most susceptible lines were Tara, 7P116 and 8 GH 85-2. These breeding lines could be used as susceptible checks for further bioassay tests to evaluate various fodder soybean breeding lines for antibiosis against corn earworm. The breeding lines, which have shown some antibiosis to corn earworm, need to be evaluated for multiple insect pest resistance. The ecological and economic benefits of host plant resistance in fodder soybean including the reduction in the use of pesticides are important and can not be overemphasized.

Acknowledgements: The project was supported by the CSREES Capacity Building Grant Program of United States Department of Agriculture (USDA) and the authors are grateful to the agency for providing funding for this study. We also thank Dr. T.E. Devine, Sustainable Agricultural System Laboratory, USAD-ARS, Beltsville, MD 20705, USA for providing the seeds and for his valuable comments on the manuscript. Thanks are also due to Mr. Khalid Abou-Zeid and Dr. Bessie Green and for technical assistance.

\section{REFERENCES}

Beach R.M., Todd J.W. (1988) Foliage consumption and development parameters of soybean looper and velvet caterpillar (Lepidoptera: Noctuidae) reared on susceptible and resistant genotypes, J. Econ. Entomol. 65, 193-195.

Beland G.L., Hatchett J.H. (1976) Expression of antibiosis to bollworm in two soybean genotypes, J. Econ. Entomol. 69, 557-560.
Devine T.E., Hatley E.O. (1998) Registration of 'Donegal' forage soybean, Crop Sci. 38, 1719-1720

Devine T.E., Hatley E.O., Starner D.E. (1998) Registration of 'Derry' forage soybean, Crop Sci. 38, 1719-1720.

Devine T.E., Hatley E.O., Starner D.E. (1998b) Registration of 'Tyrone' forage soybean, Crop Sci. 38, 1720.

Douce G.K., Suber E.F. (1986) Summary of losses from insect damage and costs of control in Georgia, 1985, Georgia Agricultural Experiment Station Special Publication 40, Athens.

Duncan D.B. (1955) Multiple range and multiple F tests, Biometrics 11, $1-42$.

Eckel C.S., Bradly J.R. Jr., Van Duyn J.W. (1992) Reduction in soybean yield and quality from corn earworm flower feeding, Agron. J. 84, 402-409.

Gary D.J., Lambert L., Oust J.D. (1985) Evaluation of soybean plant introductions for resistance to foliar feeding insects, J. Mississippi Acad. Sci. 30, 67-82.

Hatchett J.H., Beland G.L. Hartwig E.E. (1976) Leaf feeding resistance to bollworm and tobacco budworm in three soybean plant introductions, Crop Sci.16, 277-280.

Hatchett J.H., Beland G.L., Hartwig E.E. (1979) Leaf-feeding resistance to bollworm and tobacco budworm in three soybean plant introductions, Crop Sci. 16, 277-280.

Hintz R.W., Albrecht K.A. Oplinger E.S. (1992) Yield and quality of soybean forage as affected by cultivar and management practices, J. Am. Soc. Agron. 84, 795-798.

Javaid I., Joshi J.M. (1995) Trap Cropping in Insect Pest Management, J. Sustain. Agr. 5, 117-136.

Javaid I., Joshi J.M., Dadson R.B., Nobakht M. (1991) Evaluation of soybean breeding lines for antibiosis to corn earworm (Lepidoptera: Nocuidae), J. Plant Prot. Tropics 8, 125-130.

Johnson M.W., Stinner R.E., Tabb R.L. (1975) Ovipositional response of Heliothis zea (Boddie) to its major hosts in North Carolina, Environ. Entomol. 4, 291-297.

Joshi J.M. (1981) Laboratory studies of antibiosis of foliage of certain soybean cultivars on immature stages of Heliothis zea, Field Crops Res. 4, 47-54.

Joshi J.M., Javaid I., Dadson R.B., Nobakht M. (1992) Antibiosis to corn earworm (Helicoverpa zea Boddie) by vegetable soybean cultivars, J. Agron. Crop Sci. 196, 355-357.

Koivisto J.M., Devine T., Lane P.F.G., Sawyer C.A., Brown H.J. (2003) Forage soybean (Glycine max (L.) Merr.) in the United Kingdom: test of new cultivars, Agronomie 23, 287-291.

Kraemer M.E. (2001) Insect resistance in vegetable and tofu soybeans, J. Entomol. Sci. 36, 57-66.

Kraemer M.E., Rangappa M., Mohamed A. (1997) Evaluation of vegetable soybean genotypes for resistance to corn earworm (Lepidoptera: Noctuidae), J. Entomol. Sci. 32, 25-36.

Mebrahtu T., Kraemer M. Anderhan T. (2002) Evaluation of soybean breeding lines for resistance to corn earworm, Crop Sci. 42, 1465-1470.

Nayighugu V., Kellogg D.D, Longer D.E., Johnson Z.B., Anschutz K.A., Devine T.E. (2002) Case study: Performance and ensiling characteristics of tall-growing soybean lines used for silage, Prof. Anim. Sci. 18, 85-89.

Painter R.H. (1991) Insect resistance in crop plants, MacMillan, New York. 
Paschal E.H., Rogers C.E. (1980) Soybean breeding for resistance to foliage feeding arthropods, Texas Agricultural Experiment Station, College Station, Texas, No. 1451, 390-397.

Pedigo L.P. (1989) Entomology and Pest Management, McMillan Publishing Company, New York, p. 646.

SAS Institute. (1996) SAS users' guide: Statistics, 5th ed., SAS Institute, Cary, NC.

Seiter S., Altemose C.E., Davis M.H. (2004) Forage soybean and quality responses to plant density and row distance, Agron. J. 96, 966-970.

Sheaffer C.C., Orf J.H., Devine T.E., Jewett J.D. (2001) Yield and quality of forage soybean, Agron. J. 93, 99-106.
Singh S.R. (1987) Host plant resistance for cowpea insect pest management, Insect Sci. Appl. 8, 765-769.

Smith R.H., Bass M.H. (1972) Soybean response to various levels of pod damage, J. Econ. Entomol. 65, 193-195.

Steel R.G.B., Torrie J.H. (1980) Principles and Procedures of Statistics, McGraw, New York.

Stinner R.E., Bradley J.R. Jr., Duyn V. (1980) Sampling Heliothis spp. on soybean, P 07-421, in: Kogan M., Herzog D.C. (Eds.), Sampling methods in soybean entomology, Springer-Verlag, New York.

Wiseman B.R. (1985) Types and mechanism of host plant resistance to insect attack, Insect Sci. Appl. 6, 239-242. 